\title{
Use of P for three potato clones in soil and in soilless cultivation
}

\author{
Darlene Sausen ${ }^{1 *}$, Ivan Ricardo Carvalho ${ }^{2}$, Márcio Renan Weber Schorr ${ }^{3}$, Miriam da Silva Tavares ${ }^{4}$, Aline \\ Soares Pereira' ${ }^{1}$, Athos Odin Severo Dorneles ${ }^{1}$, Daniele Bernardy ${ }^{1}$, Francine Lautenchleger ${ }^{5}$, Dilson \\ Antônio Bisognin ${ }^{1}$, Fernando Teixeira Nicoloso ${ }^{1}$
}

\author{
${ }^{1}$ Federal University of Santa Maria, Santa Maria, RS, Brazil \\ ${ }^{2}$ Regional University of the Northwest of the State of Rio Grande do Sul, Ijuí, RS, Brazil \\ ${ }^{3}$ National Supply Company, Porto Alegre, RS, Brazil \\ ${ }^{4}$ Goiás State University, Posse, GO, Brazil \\ ${ }^{5}$ University of the Midwest, Guarapuava, PR, Brazil
}

*Corresponding author: darlene_sn@yahoo.com.br

\begin{abstract}
The objective of this work was to verify the nutritional efficiency to phosphorus $(P)$ as well as the responses of the use of $P$ for three potato clones in soil and soilless cultivation (semi hydroponic). For this purpose, the Asterix, SMIC 148-A and SMINIA 793101-3 clones were evaluated under high and low $\mathrm{P}$ levels in soil growing (70 and $560 \mathrm{~kg}_{2} \mathrm{O}_{5}$ ha-1) and in soilless cultivation using sand as substrate (2.32 and $23.2 \mathrm{mg} \mathrm{P} \mathrm{L}^{-1}$ of nutritive solution). Rooting efficiency, absorption, translocation and use of $\mathrm{P}$, fresh tuber mass, total dry mass and harvest index were evaluated in the clones. Each clone responds differently to the growing systems used in terms of nutritional efficiency for P. In both growing systems, the Asterix, SMIC 148-A and SMINIA 793101-3 clones did not show any increase in the absorption efficiency and in the efficiency of using $P$ to compensate for the low level of $P$, which may have caused the reduction in total dry mass under low $\mathrm{P}$. The restriction of $\mathrm{P}$ causes a reduction in tuber fresh mass for the Asterix and SMINIA 793101-3 clones in the two growing systems tested and for the SMIC 148-A clone only in soilless cultivation. Asterix is the clone with the highest harvest index under low $\mathrm{P}$ in the field, even without differing from the others in soilless cultivation.
\end{abstract}

\section{Introduction}

The sustainability of the potato production system (Solanum tuberosum L.) requires a reduction in the use of inputs, especially mineral fertilizers whose sources are not renewable, such as phosphates. Therefore, it is necessary to improve the management of the use of fertilizers and select genotypes that have high yield and quality, even under nutrient limiting conditions.

With the improvement of the nutritional efficiency of cultivated plants, productivity is increased and the use of fertilizers is reduced, with a consequent reduction in costs (Gondim et al., 2010). Nutritional efficiency is dependent on two main factors: the acquisition and use of $P$. The first is influenced by kinetic (absorption) and morphological (rooting) parameters, while the second depends on translocation and conversion to biomass (use) (Fox, 1978; Moura et al., 2001). Thus, the nutritional efficiency of $P$ is related to the higher production of biomass associated with lower consumption of $P$, under conditions of adequate or limited supply.

The difference between clones in terms of nutritional efficiency to $P$ is explained by different morphological, physiological, biochemical and molecular mechanisms (Gaxiola et al., 2011; Plaxton and Tran, 2011). The existence of this variability is what allows us to select those clones that show rapid growth and low demand for phosphate fertilizers in the field (Fernandes et al., 2017; Sorato and Fernandes, 2016; Sorato et al., 2015) and soilless cultivation (Sausen et al., 2020a; Sausen et al., 2020b; Sausen et al., 2020c; Martins et al., 2018).

In order to facilitate the selection process of the most efficient potato clones to $P$, in addition to assisting in the production of quality seed potatoes, soilless cultivation have been used, which allow better control of nutrient concentrations (Sausen et al., 2020d; Bisognin et al., 2015). Thus, the objective of this work was to verify the nutritional efficiency of $P$ as well as the responses of the use of $P$ for three potato clones in soil and in soilless cultivation.

\section{Results and discussion}

In response to a condition of $\mathrm{P}$ restriction, the plants promote some changes in the morphology and architecture of the root system seeking to increase the surface of $P$ acquisition (Gaxiola et al., 2011). The potato plant has the characteristic of having a small root system and in the present study carried out in soil, it was found that the root system little developed to contribute to the acquisition of $P$ in the condition of nutrient limitation, since it invested little in the production of roots dry mass when low in P (Table 1). Compared with the growth of the plant shoot, root growth is less affected under $P$ deficiency, a fact that leads to a decrease in the shoot / root ratio (Smith et al., 1990). Thus, it is evident that this adaptive mechanism to circumvent the 
low availability of $P$ was not expressed in the potato, or occurred for a short time.

Contrary to what was observed for potato clones in the soil, in the soilless cultivation, rooting efficiency (RE) was different between the $\mathrm{P}$ levels for the three potato clones, being higher at the low $P$ level (Table 1 ). In low concentrations of $P$, plants direct the photoassimilates to the growth of the roots to the detriment of the shoot, a fact that increases the exploration of a larger volume of substrate (Niu et al., 2012). That is, at the time the plants were evaluated, the potato clones showed superior growth and development of the root system in response to the low $P$ condition. This may have occurred as a result of the increase in the growth rate in root extension, increase in the formation of lateral roots or root hairs (Abel et al., 2002), promoting greater acquisition of $\mathrm{P}$ from the nutrient solution. This relationship between root parameters and nutritional efficiency to $\mathrm{P}$ has also been suggested in studies comparing genotypes of beans (Liao et al., 2001) and wheat (Silva et al., 2015) under low level of $P$ in the soil, where plants with low efficiency of $P$ absorption (PAE) showed greater volume and length of roots than plants with high PAE.

An improvement in the nutritional efficiency of $P$ can be obtained through the selection of potato clones with a greater capacity to absorb $P$ from the soil in a nutrient limiting condition (Balemi, 2011). In the early stages of plant growth and development, the absorption of $\mathrm{P}$ by the roots is the largest source of $P$ for the plant. Thus, clones with a superior capacity to absorb $P$ from the substrate ensure the proper formation of their tissues and organs (Pinto et al., 2011). However, for the three clones, in both growings, there was no increase in PAE to compensate for the low level of $P$ (Table 1). On the contrary, in soil growing, the Asterix clone showed a $12 \%$ reduction in PAE in the low level of $P$ and in soilless cultivation the PAE was also lower in the low level of $P$ for the Asterix and SMINIA 793101-3 clones, in 92 and $87 \%$, respectively (Table 1 ). Both experiments were evaluated in the tuberization phase, where there is a change in the source of $P$ supply to the plant, which can be intensified with the restriction of $P$, so that the main source of $P$ for growth may have become the $P$ remobilized from other tissues and no longer the $P$ absorbed from the soil (Plaxton and Tran, 2011).

Another factor that can influence the nutritional efficiency of $P$ is the transport of $P$ from the absorption site in the root to another point, inside or outside the root. In soil growing, the translocation of $P$ from the roots to the shoot was not a limiting mechanism to the metabolic process of $P$ assimilation, since the clones transported $30 \%$ more $P$ to the shoot when subjected to the low level of $P$ in the soil (Table 1). However, in soilless cultivation, the Asterix clone did not differ in $\mathrm{P}$ translocation efficiency (PTE) between $\mathrm{P}$ levels, but SMIC 148-A and SMINIA 793101-3 clones showed higher PTE at high P level, 41 and $49 \%$ respectively. Generally, plants deficient in $P$ retain more $P$ in the roots and translocate it less to the shoot to maintain the growth of the root system, as a priority, and to increase the acquisition of $P$ to reestablish the metabolism.

The internal capacity of the plant to use $P$ also interferes with nutritional efficiency. According to Balemi and Schenk (2009) the difference in the nutritional efficiency of $P$ between potato clones is a result of the $P$ use efficiency (PUE) and not of PAE. In this work, the PUE in soil growing for clones Asterix and SMIC 148-A increased 46 and $94 \%$ and in soilless cultivation the clone SMINIA 793101-3 showed an increase of $52 \%$ when grown at the high level of $P$ (Table 1 ). These results contradict a large number of studies that show that the more $\mathrm{P}$ available to plants, the lower the PUE (Gondim et al., 2010; Moura et al., 2001). These discrepancies are probably related to the clones and the experimental conditions used.

Regarding the production of biomass of commercial interest, in both crops, the three clones showed higher production of tuber fresh mass (TFM) under high level of $P$, despite the SMIC 148-A having no difference between the levels of $P$ in the soil growing. This increase was 193 and $71 \%$ for the Asterix and SMINIA 793101-3 clones, respectively, in soil growing and 108, 96 and $287 \%$ for the Asterix, SMIC 148-A and SMINIA 793101-3 clones, respectively. (Table 1). These results help to confirm the effects that $P$ promotes on tubers, already mentioned by Prezotti et al. (1986), stimulating the formation of large tubers, speeding up maturation and reducing the crop cycle. Due to the large participation of tubers in the total dry mass (DM Total), this variable showed the same response as DM Total for the three clones in the two growing systems, with lower production of DM Total in the low level of $P$, except for the SMINA 793101-3 clone, that showed no difference between $P$ levels in soil growing (Table 1). It was observed, in soil growing, under low $\mathrm{P}$ level a reduction of 37 and $26 \%$ in DM Total, respectively for the Asterix and SMIC 148-A clones, whereas in soilless cultivation, in low $\mathrm{P}$ level, the reduction in DM Total of the Asterix, SMIC 148-A and SMINIA 793101-3 clones was 57,42 , and $73 \%$, respectively (Table 1 ). Balemi (2009), in a study evaluating the nutritional efficiency of $P$ among contrasting potato clones regarding the efficiency of $P$, also observed that the restriction of $P$ affected the DM Total of inefficient $P$ clones more severely, where the reduction in the low level of $\mathrm{P}$ reached $75 \%$ of the DM Total, while for efficient $\mathrm{P}$ clones this reduction was close to $30 \%$. Thus, in the present study, the SMIC 148-A clone, for presenting a reduction in DM Total less than $30 \%$, was classified as efficient for $P$ in soil growing. The SMINIA 793101-3 clone, on the other hand, is inefficient for $P$ in soilless cultivation, due to a reduction in DM Total close to $75 \%$.

As for the $\mathrm{HI}$, which refers to the fraction of the tubers in relation to the total biomass of the plant, in soil growing the restriction of $\mathrm{P}$ caused a reduction in the $\mathrm{HI}$ by $16 \%$, and among the clones Asterix had the highest $\mathrm{HI}(40 \%)$ ), followed by SMINA 793101-3 (33\%) and SMIC 148-A (23\%) (Table 1). In the soilless cultivation, the $\mathrm{P}$ restriction caused a $7 \%$ reduction in the $\mathrm{HI}$ for the Asterix clone, an increase of $8 \%$ for the SMIC 148-A clone and did not affect the $\mathrm{HI}$ of the SMINIA 793101-3 clone (Table 1). At the high level of $P$, the highest $\mathrm{HI}$ was observed for the Asterix clone (77\%), however, at the low level it was not possible to differentiate the clones, as was the case for all other variables analyzed in this study in soilless cultivation, making it possible to assume that in this system, the restriction of $P$ is limiting the yield of the crop.

The $\mathrm{HI}$ values found in this study ranged from 22 to $44 \%$ (Table 1) for clones grown in soil, close to the HIs found by Bisognin and Dellai (2015) for the cultivars Macaca and Asterix, which ranged from 0.2 to 0,6 depending on the growing season, but very low for a potato growing in soil, where it is expected to find $\mathrm{HI}$ greater than 0.6 as those already reported by Belanger et al. (2001) and Mazurczyk et al. (2009). The soilless cultivation, on the other hand, 
Table 1. Rooting, absorption, translocation and utilization efficiency of $P$, fresh tuber mass, total dry mass of the plant and harvest index of potato clones grown in soil evaluated at 73 DAP and grown out of soil with sand as substrate evaluated at 62 DAT. Santa Maria, RS, 2017.

\begin{tabular}{|c|c|c|c|c|c|c|c|c|}
\hline \multirow{3}{*}{ Level of $P$} & \multicolumn{3}{|c|}{ Soil growing } & \multirow{3}{*}{ Average } & \multicolumn{3}{|c|}{ Off-soil growing } & \multirow{3}{*}{ Average } \\
\hline & & & SMINIA & & \multirow[b]{2}{*}{ Asterix } & \multirow{2}{*}{$\begin{array}{l}\text { SMIC } \\
148-A\end{array}$} & \multirow{2}{*}{$\begin{array}{l}\text { SMINIA } \\
793101-3\end{array}$} & \\
\hline & Asterix & SMIC 148-A & $793101-3$ & & & & & \\
\hline \multicolumn{9}{|c|}{ Rooting efficiency at $\mathrm{P}(\mathrm{RE})\left(\mathrm{g}^{2} \mathrm{msr} \mathrm{mg}^{-1} \mathrm{P}\right.$ in the shoot) } \\
\hline High & 0.24 & 0.18 & 0.29 & $0.2 \mathrm{~A}$ & $0.00 \mathrm{Bb}$ & $0.01 \mathrm{Ba}$ & $0.00 \mathrm{Bb}$ & 0.00 \\
\hline Low & 0.13 & 0.12 & 0.17 & $0.1 \mathrm{~B}$ & $0.02 \mathrm{Aa}$ & $0.02 \mathrm{Aa}$ & $0.02 \mathrm{Aa}$ & 0.02 \\
\hline Average & $0.18 \mathrm{~b}$ & $0.15 b$ & $0.23 \mathrm{a}$ & & 0.01 & 0.01 & 0.01 & \\
\hline CV (\%) & 13.90 & & & & 27.34 & & & \\
\hline \multicolumn{9}{|c|}{ P absorption efficiency (PAE) (mg g ${ }^{-1}$ ) } \\
\hline High & $56.43 \mathrm{Aa}$ & $35.66 \mathrm{Ab}$ & 45.06 Aab & 45.7 & $628.80 \mathrm{Aa}$ & $129.90 \mathrm{Ac}$ & $479.76 \mathrm{Ab}$ & 412.8 \\
\hline Low & $49.46 \mathrm{Ba}$ & $41.51 \mathrm{Ab}$ & 46.19 Ac & 45.7 & 49.34 Ba & $52.63 \mathrm{Aa}$ & $64.27 \mathrm{Ba}$ & 55.4 \\
\hline Average & 52.94 & 38.58 & 45.63 & & 339.07 & 91.27 & 272.01 & \\
\hline CV (\%) & 9.21 & & & & 24.75 & & & \\
\hline \multicolumn{9}{|c|}{ P translocation efficiency (PTE) } \\
\hline High & 50.98 & 66.21 & 47.89 & $55.0 \mathrm{~B}$ & $30.87 \mathrm{Aa}$ & $38.34 \mathrm{Aa}$ & $41.08 \mathrm{Aa}$ & 36.8 \\
\hline Low & 69.27 & 77.57 & 67.30 & $71.4 \mathrm{~A}$ & $31.50 \mathrm{Aa}$ & $27.19 \mathrm{Ba}$ & $27.49 \mathrm{Ba}$ & 28.7 \\
\hline Average & $60.13 b$ & $71.89 \mathrm{a}$ & $57.60 \mathrm{~b}$ & & 31.19 & 32.76 & 34.28 & \\
\hline CV (\%) & 7.88 & & & & 17.62 & & & \\
\hline \multicolumn{9}{|c|}{$\mathrm{P}$ use efficiency (PUE) $\left(\mathrm{g}^{2} \mathrm{mg}^{-1}\right)$} \\
\hline High & $31.85 \mathrm{Aa}$ & $16.89 \mathrm{Ac}$ & $25.16 \mathrm{Ab}$ & 24.6 & $5.34 \mathrm{Ab}$ & $4.07 \mathrm{Ab}$ & $8.03 \mathrm{Aa}$ & 5.8 \\
\hline Low & $21.76 \mathrm{Ba}$ & $8.71 \mathrm{Bb}$ & $22.68 \mathrm{Aa}$ & 17.7 & $5.52 \mathrm{Aa}$ & $5.79 \mathrm{Aa}$ & $5.29 \mathrm{Ba}$ & 5.5 \\
\hline Average & 26.81 & 12.80 & 23.92 & & 5.43 & 4.93 & 6.66 & \\
\hline CV (\%) & 10.68 & & & & 22.19 & & & \\
\hline \multicolumn{9}{|c|}{ Tuber fresh mass (TFM) $\left(\mathrm{g} \mathrm{pl}^{-1}\right)$} \\
\hline High & $300.2 \mathrm{Aa}$ & $77.30 \mathrm{Ac}$ & $199.33 \mathrm{Ab}$ & 192.3 & $77.51 \mathrm{Ab}$ & $62.84 \mathrm{Ab}$ & $122.31 \mathrm{Aa}$ & 87.5 \\
\hline Low & 101.3 Bab & $37.15 \mathrm{Ab}$ & $116.56 \mathrm{Ba}$ & 85.0 & $37.21 \mathrm{Ba}$ & $32.02 \mathrm{Ba}$ & $31.57 \mathrm{Ba}$ & 33.6 \\
\hline Average & 200.8 & 57.23 & 157.95 & & 57.36 & 47.43 & 76.94 & \\
\hline CV (\%) & 29.55 & & & & 23,96 & & & \\
\hline \multicolumn{9}{|c|}{ Total dry mass (DM Total) ( $\mathrm{g} \mathrm{p}^{-1}$ ) } \\
\hline High & $108.93 \mathrm{Aa}$ & $50.19 \mathrm{Ac}$ & $82.66 \mathrm{Ab}$ & 80.6 & $19.78 \mathrm{Ab}$ & $15.83 \mathrm{Ab}$ & $34.70 \mathrm{Aa}$ & 23.4 \\
\hline Low & $68.48 \mathrm{Ba}$ & $37.15 \mathrm{Bb}$ & $74.50 \mathrm{Aa}$ & 60.0 & $8.55 \mathrm{Ba}$ & $9.18 \mathrm{Ba}$ & $9.22 \mathrm{Ba}$ & 9.0 \\
\hline Average & 88.70 & 43.67 & 78.58 & & 14.17 & 12.51 & 21.96 & \\
\hline CV (\%) & 10.82 & & & & 22.19 & & & \\
\hline \multicolumn{9}{|c|}{ Harvest index (HI) (\%) } \\
\hline High & 44.26 & 23.22 & 36.83 & $34.8 \mathrm{~A}$ & $76.70 \mathrm{Aa}$ & $68.80 \mathrm{Bb}$ & $70.20 \mathrm{Ab}$ & 0.7 \\
\hline Low & 35.92 & 22.75 & 28.65 & 29.1 B & $71.00 \mathrm{Ba}$ & $74.60 \mathrm{Aa}$ & $71.00 \mathrm{Aa}$ & 0.7 \\
\hline Average & $40.09 a$ & $22.99 \mathrm{c}$ & $32.74 \mathrm{~b}$ & & 73.85 & 71.70 & 70.60 & \\
\hline CV (\%) & 16.94 & & & & 4.85 & & & \\
\hline
\end{tabular}

showed $\mathrm{HI}$ that exceeded expectations, greater than $69 \%$ (Table 1) for all clones, showing that in addition to the genetic characteristics of the clones, the conditions of the growing system can also provide a change in the $\mathrm{HI}$ for potato clones.

\section{Materials and methods}

\section{Plant materials, treatments and conduction of study}

The experiment in soil (field) was installed in the spring of 2013 (from 09/05 to 12/19) in an experimental area of the Federal University of Santa Maria, Santa Maria - RS (29043'38"S, 5343'21 "W and altitude of 95m), in soil of the type Umbric Alkyd Bruno-Gray Argisol (Ultisol) (Embrapa, 2013). The area had been prepared for planting in 2008 (liming and fertilization) but had not been cultivated for five years and had a very low $\mathrm{P}$ content $\left(1.5 \mathrm{mg} \mathrm{dm}^{-3}\right), \mathrm{pH}$ in water 6.1, $\mathrm{CEC}_{\mathrm{pH} 7.0}$ 10.4, OM 5.4\% and $\mathrm{K} 55 \mathrm{mg} \mathrm{dm}^{-3}$ at a depth of $0-0.20 \mathrm{~cm}$. The soil preparation was carried out in a conventional manner. The seed tubers were sown at a spacing of $0.8 \mathrm{~m}$ between rows and $0.35 \mathrm{~m}$ between tubers. The sowing fertilization was carried out in the planting furrow based on the results of the chemical analysis of the 0 $0.20 \mathrm{~cm}$ layer. Phosphorus was added in the form of triple superphosphate (0-42-0), nitrogen in the form of urea and potassium in the form of potassium chloride. The other crop treatments and crop management were carried out according to the technical recommendations for the growing of potatoes (Bisognin, 1996).

For the experiment in the soilless cultivation (closed semi hydroponic system), the same potato clones, previously micropropagated in MS growing medium (Murashige and Skoog, 1962), kept in a growth room for 14 days were used, and then the plants were removed from the MS medium, had their roots washed in tap water and acclimatized for another 14 days in a soilless cultivation with sand as a substrate (Bandinelli et al., 2013), kept under shade (60\% of light extinction) during the first five days. In this system composed of trays, the sand used was previously washed once with sodium hypochlorite and three times with tap water. During the day, three irrigations were carried out with a nutritive solution, each lasting 15 minutes, with the aid of a digital programmer and a low-flow pump so that the entire substrate was saturated with solution. The excess solution was drained through a hole located at the base of the tray. After that period, the plants were transplanted to a sand cultivation system similar to the one used for acclimatization, where twelve plants remained in each tray in a 10 by $10 \mathrm{~cm}$ spacing. Phosphorus treatments consisted 
of 5 and $50 \%$ of the standard concentration of $P$ in the nutrient solution described by Bisognin et al. (2015) for soilless potato cultivation, called low $\left(2.32 \mathrm{mg} \mathrm{P} \mathrm{L}^{-1}\right)$ and high (23.2mg $\mathrm{P} \mathrm{L} \mathrm{L}^{-1}$ ) $\mathrm{P}$ levels in this work. To maintain the potassium content of the standard solution, $\mathrm{KCl}$ was used. The electrical conductivity (EC) was maintained at $2 \mathrm{dS} \mathrm{m}^{-1} \pm$ 0.2 (water was used to reduce the EC when necessary) and the $\mathrm{pH}$ at 5.7 adjusted every two days by adding $\mathrm{HCl}$.

\section{Experimental design}

The experimental design used in the soil experiment was completely randomized, with four replications, where each level of $P$ represented an environment and within each environment, treatments (clones) were randomized. The experimental unit consisted of 2 rows of $5 \mathrm{~m}$ in length, with $0.7 \mathrm{~m}$ being discarded at the end of each row, in addition two lines of boundary surrounded the whole experiment. Potato clones SMIC 148-A and SMINIA 793101-3 and the cultivar Asterix (referred to as a clone for simplification purposes) and two levels of $\mathrm{P}$, called in this work low and high levels of $P\left(70\right.$ and $560 \mathrm{~kg}_{2} \mathrm{O}_{5}$ ha $\left.^{-1}\right)$. The soilless experiment was conducted in a greenhouse, in a randomized block design, using four replications. The experimental unit consisted of three plants.

\section{Characters measured}

At 73 days after planting (DAP) for the experiment in soil and at 62 days after transplanting (DAT) for the soilless experiment, the plants were washed with tap water and divided into shoots, tubers and roots. The tuber fresh mass (TFM) was evaluated (in grams) and after drying the material for 15 days in an oven at $65^{\circ} \mathrm{C}$, the shoots (SDM), tubers (TDM) and roots (RDM) dry mass were also evaluated, and then the samples were macerated manually. The analysis of the total phosphorus concentration in the tissues was performed according to Tedesco et al. (1995), with the digestion of $0.2 \mathrm{~g}$ of tissue with $0.7 \mathrm{~g}$ of digestion mixture ( $100 \mathrm{~g}$ of $\mathrm{Na}_{2} \mathrm{SO}_{4}, 10 \mathrm{~g}$ of $\mathrm{CuSO}_{4} .5 \mathrm{H}_{2} \mathrm{O}$ and $1 \mathrm{~g}$ of selenium) in sulfuric acid $\left(\mathrm{H}_{2} \mathrm{SO}_{4}\right)$ with hydrogen peroxide $\left(\mathrm{H}_{2} \mathrm{O}_{2}\right)$ remaining in digestion block for one hour at $350 \stackrel{\circ}{\circ}$. The determination of $\mathrm{P}$ in plant tissue extracts was performed by colorimetry, according to Murphy and Riley (1962). The accumulation of $\mathrm{P}$ in the tissues was obtained by the product between the concentration of $P$ and the dry mass of each organ of the plant. Once these data were obtained, the following efficiency indexes were estimated: i) rooting efficiency (RE): (root dry mass) ${ }^{2}$ / $\mathrm{P}$ accumulation in the shoot, according to Siddiqi and Glass (1981); ii) P absorption efficiency (PAE): $P$ accumulation in the plant / dry root mass, according to Swiader et al. (1994); iii) P translocation efficiency (PTE): accumulation of $P$ in the shoot / accumulation of total $\mathrm{P}$, according to $\mathrm{LI}$ et al. (1991); iv) $\mathrm{P}$ use efficiency (PUE): (total dry mass of the plant) 2 / P accumulation in the entire plant, according to Siddiqi and Glass (1981); v) harvest index (HI): \{[(tubers dry mass) / (total dry mass of the plant)] $\left.{ }^{*} 100\right\}$, according to Nautyal et al. (2002).

\section{Statistical analysis}

For the joint analysis of the data from the soil experiment, the statistical software Genes (Cruz, 2006) was used and for the statistical analysis of the data from the soilless experiment, the Sisvar 5.3 software (Ferreira, 2011). Analysis of variance and comparison of means were performed using the Tukey test at $5 \%$ probability.

\section{Conclusion}

Each clone responds in a different way to the growing systems used in terms of nutritional efficiency to $P$. In soil and soilless cultivation, the Asterix, SMIC 148-A and SMINIA 793101-3 clones do not show an increase in absorption efficiency and in the $P$ use efficiency to compensate for the low level of $P$ which may have caused the reduction in total dry mass under low $P$. But the restriction of $P$ causes a reduction in the tuber fresh mass for the Asterix and SMINIA 793101-3 clones in the two growing systems tested and for the SMIC 148-A clone only in soilless cultivation. Asterix is the clone with the highest harvest index under low $\mathrm{P}$ in the field, even without differing from the others in soilless cultivation. The closed soilless cultivation with the use of sand as a substrate overestimates the responses of potato clones in relation to the availability of $\mathrm{P}$ and can compromise the selection of genotypes in relation to their real performance in the field.

\section{Acknowledgements}

We thank the Coordenação de aperfeiçoamento de pessoal de nível superior (CAPES) for research productivity scholarship for first author, and to the Potato Breeding Program at UFSM for granting genotypes.

\section{References}

Abel S, Ticconi CA, Delatorre CA (2002) Phosphate sensing in higher plants. Physiol Plant. 115:1-8.

Balemi T (2009) Effect of phosphorus nutrition on growth of potato genotypes with contrasting phosphorus efficiency. African Crop Sci J. 17:199-212.

Balemi T, Schenk MK (2009) Genotypic difference of potato in carbon budgeting as a mechanism of phosphorus utilization efficiency. Plant Soil. 322:91-99.

Balemi T (2011) Screening for genotypic variation in potato for phosphorus efficiency. Int Resear J Plant Sci. 2:233-243. Bandinelli MG, Bisognin DA, Gnocato FS, Mambrin RB, Sausen D, Nicoloso FT (2013) Concentração dos sais e da sacarose do meio ms na multiplicação in vitro e na aclimatização de batata. Hortic Bras. 31:242-247.

Bélanger G, Walsh JR, Richards JE, Milbum PH, Ziadi N (2001) Tuber growth and biomass partitioning of two potato cultivars grown under different $\mathrm{N}$ fertilization rates with and without irrigation. Am J Potato Research. 78:109-117.

Bisognin DA (1996) Recomendações técnicas para o cultivo da batata no Rio Grande do Sul e Santa Catarina. Santa Maria. 64.

Bisognin DA, Bandinelli MG, Kielse P, Fischer H (2015) Rooting potential of mini-cuttings for the production of potato plantlets. A J Plant Sci. 6:366-371.

Bisognin DA, Dellai J (2015) Shoot growth restriction in dry matter partitioning and minituber production of potato plants. Ciên Rural. 45:1917-1924.

Cruz CD (2006) Programa Genes. Viçosa. 382.

Embrapa. (2013) Sistema brasileiro de classificação de solos. 2ed. Rio de Janeiro. 306.

Ferreira DF (2011) Sisvar: A computer statistical analysis system. Ciên Agrotec. 35:1039-1042. 
Fox RH (1978) Selection for phosphorus efficiency in corn. Commun Soil Sci Plant Analysis. 9:13-37.

Gaxiola RA, Edwards M, Elser JJ (2011) A transgenic approach to enhance phosphorus use efficiency in crops as part of a comprehensive strategy for sustainable agriculture. Chemosphere, 84:840-845.

Gondim ARO, Prado RM, Alves AU, Fonseca IM (2010) Eficiência nutricional do milho cv. BRS 1030 submetido à omissão de macronutrientes em solução nutritiva. Rev Ceres. 57:539-544.

Li B, Mckeand SE, Allen HL (1991) Genetic variation in nitrogen use efficiency of loblolly pine seedlings. Forest Sci. 37:613-626.

Liao H, Rubio G, Yan X, Cao A, Brown KM, Lynch LP (2001) Effect of phosphorus availability on basal root shallowness in common bean. Plant Soil. 232:69-79.

Martins JDL, Soratto RP, Fernandes AM, Dias PHM (2018) Phosphorus fertilization and soil texture affect potato yield. R Caatinga. 31:541-550.

Mazurczyk W, Wierzbicka A, Trawczynski C (2009) Harvest index of potato crop grown under different nitrogen and water pupply. Acta Sci Polonorum. 8:15-21.

Moura WM, Lima PC, Casali VWD, Pereira PRG, Cruz CD (2001) Eficiência nutricional para fósforo em linhagens de pimentão. Hortic Bras. 19:174-180.

Murashige T, Skoog F (1962) A revised medium for rapid growth and bioassays with tobacco tissue culture. Phys Plantarum. 15:473-497.

Murphy J, Riley JP (1962) A modified single solution method for the determination of phosphate in natural waters. Analy Chimica A. 27:31-36.

Nautyal PC, Nageswara-Rao RC, Joshi YC (2002) Moisture deficit induced change in leaf water content, leaf carbon exchange rate and biomass production in groundnut cultivars differing in specific leaf area. Field Crops Resear. 74:67-79.

Niu YF, Chai RS, Jin GL, Wang H, Tang CX, Zhang YS (2012) Responses of root architecture development to low phosphorus availability: a review. Annals of Botany. 112:391-408.

Pinto SIC, Furtini Neto AE, Neves JCL, Faquin V, Moretti BS (2011) Eficiência nutricional de clones de eucalipto na fase de mudas cultivados em solução nutritiva. Rev Bras Ciênc Solo. 35:523-533.
Plaxton WC, Tran HT (2011) Metabolic adaptations of phosphate-starved plants. Plant Physiol. 156:1006-1015.

Prezotti LC, Carmo CAS, Andrade Neto APM (1986) Nutrição mineral da batata. 44 .

Sausen D, Tavares MS, Schorr MRW, Thewes, FR, Ferigolo LF, Nunes PAA, Mambrin RB, Cassanego DB (2020a) Potencial produtivo de genótipos de batata provenientes de minitubérculos e micropropagação em cultivo semi hidropônico. Braz J Develop. 6:8982-8993.

Sausen D, Mambrin RB, Cassanego DB, Alves JS, Pereira AS, Dorneles AOS, Bernardy K, Schwalbert R (2020b) Produção de batata a partir de micropropagação e de minitubérculos sob níveis de fósforo em solução nutritiva. Braz J Develop. 6:6648-6657.

Sausen D, Cassanego DB, Mambrin RB, Sasso VM, Possebom G, Frari BKD, Alves JS, Marques ACR (2020c) Biomassa de clones de batata submetidos a doses contrastantes de fósforo no solo. Braz J Develop. 6:7479-7487.

Sausen D, Ferrreira CLR, Lopes SCD, Marques LP, Souza AJM, Alves ECGA Patrocínio ESA (2020d) Cultivo fora do solo: uma alternativa para áreas marginais. Braz J Develop. 6:14888-14903.

Siddiqi MY, Glass ADM (1981) Utilization index: a modified approach to the estimation and comparison of nutrient efficiency in plants. J Plant Nutr. 4:289-302.

Silva A, Bruno IP, Franzini VI, Marcante NC, Benitiz L, Muraoka T (2015) Phosphorus uptake efficiency, root morphology and architecture in Brazilian wheat cultivars. $J$ Radioan Nuclear Chemistry. 307:1055-1063.

Smith FW, Jackson WA, Berg, PJV (1990) Internal phosphorus flows during development of phosphorus stress in stylosanthes hamata. Aust J Plant Physiol. 17:451-464.

Soratto RP, Fernandes AM (2016) Phosphorus effects on biomass accumulation and nutrient uptake and removal in two potato cultivars. Soil Fert Crop Nutri. 8:1225-1236.

Soratto RP, Pilon C, Fernandes AM, Moreno LA (2015) Phosphorus uptake, use efficiency, and response of potato cultivars to phosphorus levels. Potato R. 58:121-134.

Swiader JM, Chyan Y, Freiji FG (1994) Genotypic differences in nitrate uptake and utilization efficiency in pumpkin hybrids. J Plant Nutri. 17:1687-1699.

Tedesco MJ, Gianello C, Bissani CA, Bohnen H, Wolkweiss SJ (1995) Análise de solo, plantas e outros materiais. Porto Alegre. 174. 